Rev. Int. Contam. Ambie. 36 (3) 703-710, 2020

https://doi.org/10.20937/RICA.53218

\title{
SORPTION AND LEACHING OF METALS IN THE SOIL DUE TO APPLICATION OF DISSOLVED ORGANIC MATTER
}

\author{
Adsorción y lixiviación de metales en el suelo debido a la aplicación de materia orgánica disuelta
}

\author{
Morgana SUSZEK GONÇALVES ${ }^{1 *}$, Luiz Carlos SANTOS DA SILVA JUNIOR ${ }^{2}$, \\ João Paulo BETTIN ${ }^{2}$ and Larissa KUMMER ${ }^{3}$
}

${ }^{1}$ Federal University of Technology-Paraná, Via Rosalina Maria dos Santos 1233, 97301-899, Campo Mourão, Paraná, Brazil

${ }^{2}$ Federal University of Technology-Paraná, Linha Santa Bárbara s/n, 85601-970, Francisco Beltrão, Paraná, Brazil

${ }^{3}$ Federal University of Technology-Paraná, Deputado Heitor Alencar Furtado 5000, 81280-340, Curitiba, Paraná, Brazil

*Author for correspondence: morgana@utfpr.edu.br

(Received: April 2018; accepted: June 2019)

Key words: heavy metals, pollutant transport, isotherms, cattle manure

\begin{abstract}
Agriculture is one of the most important nonpoint sources of soil contamination by heavy metals, and the presence of dissolved organic matter (DOM) in soil can influence the movement of metals. The objective of this research was to evaluate the effect of DOM on the sorption and leaching of copper $(\mathrm{Cu})$ and zinc $(\mathrm{Zn})$ in the soil. Clay soil samples collected at a $0-30 \mathrm{~cm}$ depth were used to conduct the experiments, and DOM was extracted from dairy cow manure. Soil tests to evaluaye sorption were carried out in the batch method, two treatments being considered: without the presence of $\mathrm{DOM}$ (control) and with the presence of DOM, in different concentrations of $\mathrm{Cu}$ and $\mathrm{Zn}$. Experimental results were adjusted to models of the of Langmuir and Freundlich isotherms. In the leaching experiment, columns were filled with soil previously contaminated with $\mathrm{Cu}$ and $\mathrm{Zn}$ and the distilled water was passed through them; afterwards, the leachate was collected. The sorption of copper and zinc in the soil was greater in the presence of DOM, possibly by the availability of sorption sites and interactions of metals with the DOM structure. The leaching of copper in soil was facilitated by the application of DOM, which can enable large-scale contamination of groundwater. No differences were found in zinc leaching considering water or DOM, however this metal has high mobility in the soil under study.
\end{abstract}

Palabras clave: metales pesados, transporte de contaminantes, isotermas, estiércol bovino

\section{RESUMEN}

La agricultura es una de las principales fuentes no puntuales de contaminación del suelo por metales pesados, y la presencia de materia orgánica disuelta (MOD) en el suelo puede influir en el movimiento de metales. El objetivo de este trabajo fue evaluar el efecto de la MOD en la sorción y lixiviación de cobre $(\mathrm{Cu})$ y zinc $(\mathrm{Zn})$ en el suelo. Para 
la realización de los experimentos se utilizaron muestras de suelo arcilloso recogidas a 0-30 cm de profundidad, y la MOD fue extraída de estiércol de bovinos de leche. Los ensayos de sorción en el suelo se llevaron a cabo por lotes, siendo considerados dos tratamientos: sin la presencia de MOD (control) y con la presencia de MOD, en diferentes concentraciones de $\mathrm{Cu}$ y $\mathrm{Zn}$. Los resultados fueron ajustados a los modelos de isotermas de Langmuir y Freundlich. En el experimento de lixiviación, las columnas se llenaron con suelo previamente contaminado con $\mathrm{Cu}$ y $\mathrm{Zn}$ y después se pasaron MOD o agua destilada a través de dichas columnas; posteriormente se recogió el lixiviado. La sorción de cobre y zinc en el suelo fue más alta en presencia de MOD, posiblemente por la disponibilidad de sitios sortivos e interacciones de los metales con la estructura de la MOD. La lixiviación del cobre en el suelo fue facilitada por la aplicación de MOD, lo que a gran escala puede causar contaminación de aguas subterráneas. No se observaron diferencias en la lixiviación del cinc considerando agua o MOD; sin embargo, este metal presentó alta movilidad en el suelo en estudio.

\section{INTRODUCTION}

Pollutants resulting from agricultural runoff and leaching are made up of organic matter, nutrients, agrochemicals and heavy metals. Some agricultural inputs or wastes from corrective purpose or soil nutrients such as inorganic chemical fertilizers, manures and wastewater systems for animal creations or sewage sludge, can generate serious problems when such application is made haphazardly, also representing a possible source of contamination with heavy metals.

The waste from hogs and dairy, as well as birds beds, feature high concentrations of chromium $(\mathrm{Cr})$, copper $(\mathrm{Cu})$, zinc $(\mathrm{Zn})$, iron $(\mathrm{Fe})$ and manganese $(\mathrm{Mn})$ due to unbalanced animal diets with excess of these elements. According to Scherer et al. (1996), the addition of micronutrients in excessive doses to pig's portions to ensure their absorption can lead to their accumulation in waste and the soil where they are applied. In this way, heavy metals may be bioavailable or be leached into the soil, contaminating groundwater (Sun et al. 2001, Refaey et al. 2017).

Dissolved organic matter (DOM) present in residues, whether liquid or solid, is defined by the concentration of total organic carbon in the filtered liquid extract through a $0.45 \mu \mathrm{m}$ membrane. According to Nieder et al. (2003), DOM consists of a group of molecules of different sizes and structures, and represents the most mobile and reactive organic matter in the soil.

Investigations have revealed that the presence of DOM in soil can facilitate mobility and transport of heavy metals, acting as "transporter" through the formation of soluble metal-organic complexes (Temminghoff et al. 1997, Zhou et al. 2004, Li and Zhou 2010). Thus, the application of organic materials such as manures, compost, and sewage sludge improves the physicochemical and biological conditions of the soil; however, DOM present in these wastes can affect speciation, transformation and the behavior of heavy metals in the environment (Benedetti et al. 1996).

In this context, the present study aimed to evaluate the effect of DOM from cow manure on the sorption and leaching of copper $(\mathrm{Cu})$ and zinc $(\mathrm{Zn})$ in the soil.

\section{MATERIAL AND METHODS}

\section{Soil sampling}

We collected samples of distrophic Red Umbric Latosol (Embrapa 2006) of a clay texture at a depth of $0-30 \mathrm{~cm}$. Soil had remains of roots that were manually removed, was air dried, broken down into smaller pieces and passed through a $2 \mathrm{~mm}$ sieve mesh. The determination of physicochemical characteristics of the soil (Table I) was conducted according to the methodologies described by Embrapa (1997) and Tedesco et al. (1995).

\section{Extraction of dissolved organic matter}

Dissolved organic matter (DOM) was extracted from milk cattle dung, collected in a farm with freestall system. The dung was dried and air-sieved in a $2 \mathrm{~mm}$ sieve mesh.

The extraction methodology used in the experiment was adapted from Song et al. (2008) and Yongkui et al. (2008), by mixing cow manure and deionized water at a rate of $1: 10(\mathrm{p} / \mathrm{v})$, in $200-\mathrm{rpm}$ continuous rotation for $12 \mathrm{~h}$ at room temperature. The suspension was centrifuged at $5000 \mathrm{rpm}$ for 30 min and filtered through a $0.45 \mu \mathrm{m}$ membrane, being immediately packaged and frozen for later use.

The DOM extracted was detailed (Table II) with regards to the following parameters: $\mathrm{pH}$, dissolved 
TABLE I. PHYSICAL AND CHEMICAL PROPERTIES OF THE SOIL

\begin{tabular}{lcc}
\hline \multicolumn{3}{c}{ Granulometric composition } \\
\hline Parameters & Unit & Value \\
\hline Sand & $\%$ & 10.00 \\
Silt & $\%$ & 20.00 \\
Clay & $\%$ & 70.00 \\
\hline \multicolumn{3}{c}{} \\
\hline Parameters & Chemical characteristics \\
\hline $\mathrm{pH}\left(\mathrm{CaCl}_{2}\right)$ & Unit & Value \\
$\mathrm{CEC}$ & - & 5.10 \\
$\mathrm{C}$ & $\mathrm{cmol} / \mathrm{dm}$ & 14.71 \\
$\mathrm{OM}$ & $\mathrm{g} / \mathrm{dm}$ & 20.74 \\
$\mathrm{Cu}$ & $\mathrm{g} / \mathrm{dm}$ & 35.67 \\
$\mathrm{Zn}$ & $\mathrm{mg} / \mathrm{kg}$ & 7.84 \\
\hline
\end{tabular}

CEC: cation exchange capacity, C: carbon, OM: organic matter

organic carbon (DOC), copper and zinc following the APHA (1998) methodology. Certain fractions of humic and fulvic acids, as well as humina present in DOM were also determined as per a methodology adapted from Benites et al. (2003).

TABLE II. CHARACTERIZATION OF DISSOLVED ORGANIC MATTER

\begin{tabular}{ccccccc}
\hline $\mathrm{pH}$ & $\begin{array}{c}\mathrm{DOC} \\
(\mathrm{mg} / \mathrm{L})\end{array}$ & $\begin{array}{c}\mathrm{Cu} \\
(\mathrm{mg} / \mathrm{L})\end{array}$ & $\begin{array}{c}\mathrm{Zn} \\
(\mathrm{mg} / \mathrm{L})\end{array}$ & \multicolumn{3}{c}{ Humic substances $(\mathrm{mg} / \mathrm{L})$} \\
\cline { 5 - 7 } & & & & C-HAF & C-FAF & $\mathrm{C}-\mathrm{HU}$ \\
\hline 8.47 & 325.00 & 8.19 & 393.62 & 74.2 & 23.6 & 5.00 \\
\hline
\end{tabular}

DOC: dissolved organic carbon, C-HAF: carbon in humic acid fraction, C-FAF: carbon in fulvic acid fraction, C-HU: carbon in humin fraction

\section{Sorption experiment}

Two grams of soil were placed in $50 \mathrm{~mL}$ centrifuge tubes, mixed with $10 \mathrm{~mL}$ of a $\mathrm{CaCl}_{2}(0.01 \mathrm{~mol} / \mathrm{L})$ solution containing $5,10,30,60$ and $120 \mathrm{mg} / \mathrm{L}$ of $\mathrm{Cu}^{2+}$ or $\mathrm{Zn}^{2+}$ (prepared using $\mathrm{CuCl}_{2}$ or $\mathrm{ZnCl}_{2}$ ). Using the $\mathrm{CaCl}_{2}$ solution has the purpose of avoiding eventual structural destabilization of the soil (Corrêa et al. 1999). Ten $\mathrm{mL}$ of DOM were added to the tubes, considering also a control treatment only with the mixture of soil.

The experiment was conducted by triplicate in natural soil $\mathrm{pH}$. The tubes were shaken at $250 \mathrm{rpm}$ for $12 \mathrm{~h}$ at room temperature, then centrifuged at $5000 \mathrm{rpm}$ for $10 \mathrm{~min}$. After this procedure, the resulting supernatant from centrifugation was collected and the samples were analyzed to determine the concentrations of $\mathrm{Cu}$ and $\mathrm{Zn}$ with an atomic absorption spectrophotometer.

The amount of $\mathrm{Cu}$ and $\mathrm{Zn}$ sipped in the soil was calculated based on the difference of concentration in the solution before and after the sorption experiment, according to the mass balance shown in equation 1 :

$q_{e}=\frac{\left(C_{0}-C_{e}\right) V}{m}$

where $q_{\mathrm{e}}$ is the sorbed metal concentration $(\mathrm{mg} / \mathrm{g})$, $C_{0}$ the initial metal concentration $(\mathrm{mg} / \mathrm{L}), C_{\mathrm{e}}$ the equilibrium concentration at $t$ time $(\mathrm{mg} / \mathrm{L}), V$ the volume of solution (L), and $m$ the mass of soil (g).

The experimental results were adjusted to mathematical models of Langmuir and Freundlich in their linearized forms, in accordance with the equations 2 and 3 , respectively:

$$
\begin{aligned}
& \frac{C_{e}}{q_{e}}=\frac{1}{q_{0} \cdot K_{L}}+\frac{C_{e}}{q_{0}} \\
& \log q_{e}=\log K_{F}+\frac{1}{n} \log C_{e}
\end{aligned}
$$

where $q_{0}$ is the maximum adsorption capacity $(\mathrm{mg} / \mathrm{g})$, $K_{\mathrm{L}}$ is the adsorption constant $(\mathrm{mg} / \mathrm{L})$, and $K_{\mathrm{F}}$ and $n$ are constants of the Freundlich isotherm for the ability of adsorption and adsorption intensity, respectively.

\section{Leaching experiment}

The soil used to fill the leaching columns was previously contaminated separately, using $\mathrm{Cu}$ solutions in the form of $\mathrm{CuCl}_{2} \cdot 2 \mathrm{H}_{2} \mathrm{O}$ and $\mathrm{Zn}$ as $\mathrm{ZnCl}_{2}$. The soil remained in contact with the solutions for $24 \mathrm{~h}$ on a shaker $\left(200 \mathrm{rpm} / 25^{\circ} \mathrm{C}\right)$ and was then allowed to stand. The supernatant was discarded to remove the non-adsorbed metals and the contaminated soil was oven dried at $50{ }^{\circ} \mathrm{C}$ for $24 \mathrm{~h}$ and then passed through a $2 \mathrm{~mm}$ sieve (Juwarkar et al. 2007, Franzetti et al. 2009). Soil, after the contamination, and 3025.82 and 2402.94 presented $\mathrm{mg} / \mathrm{kg}$ for $\mathrm{Cu}$ and $\mathrm{Zn}$, respectively. The $\mathrm{pH}$ of the soil after the contamination was 4.07 for $\mathrm{Cu}$ and 4.68 for $\mathrm{Zn}$.

The columns were made of PVC pipes, with 5.0 $\mathrm{cm}$ in diameter and $30 \mathrm{~cm}$ in length, fixed by vertical metal clamps in a universal mount. The total mass of soil added to the columns was of $766 \mathrm{~g}$, and soil placed on the columns was compressed in order to hinder the formation of preferential paths. Aiming to expel the air contained in the pores of the soil with the purpose of avoiding possible structural destabilization of the soil, columns were saturated with 
a low-flow solution of $\mathrm{CaCl}_{2}(0.01 \mathrm{~mol} / \mathrm{L})$ starting from the base of the column..

Once the columns were saturated and the condition of a medium flow of $8.5 \mathrm{~mL} / \mathrm{min}$ was proven, maintained with the use of a peristaltic pump, the passage of DOM or distilled water (control) in a downward flow was initiated. Twenty $50-\mathrm{mL}$ samples of leachate were collected for a total of $1000 \mathrm{~mL}$. In each sample of leachate, both $\mathrm{pH}$ and concentrations of $\mathrm{Cu}$ or $\mathrm{Zn}$ were determined by a straightforward reading in an atomic absorption spectrophotometer.

Once the concentration values of $\mathrm{Cu}$ and $\mathrm{Zn}$ in the leachate were obtained, the mass balance of metals in soil columns was calculated and the accumulated mass curves of metals in leachate, in relation to the leached volume, were built. Moreover, with the accumulated mass relationship of metal versus leached volume,we obtained the equations of regression for each treatment. In the equations of regression a straight comparison statistical test was applied to the $5 \%$ level of significance, in order to verify whether they had the same behavior.

\section{RESULTS AND DISCUSSION}

\section{Sorption of copper and zinc}

The isotherms of adsorption for copper and zinc, which relate the equilibrium concentration in the aqueous phase $(\mathrm{mg} / \mathrm{L})$ and the amount of metal adsorbed by soil $(\mathrm{mg} / \mathrm{g})$, are presented in figure $\mathbf{1}$, which demonstrates that the addition of DOM increased metals adsorption in soil.

For both heavy metals, the control treatment showed isotherms of type L, which are frequent in adsorption studies. This type of isotherm is the result of a relatively high affinity between soil particles and metal, which demonstrates that with increasing concentration the most active sites for adsorption are occupied (Sposito 1989, Antonladis and Tsadilas 2007). Thus, there is a gradual saturation of the adsorption sites until it reaches a plateau, which characterizes the maximum adsorption of ion or surface molecules of the adsorbent (Alleoni et al. 2009). This condition is observed mainly for zinc in figure $\mathbf{1 b}$, where there is a tendency to stabilize the amount of adsorbed metal from the initial concentration of $30 \mathrm{mg} / \mathrm{L}$ in aqueous solution.

In the presence of DOM, isotherms of type $\mathrm{H}$ were obtained for copper and zinc, suggesting a very high adsorption affinity in this system. This condition is normally produced by the formation of inner sphere
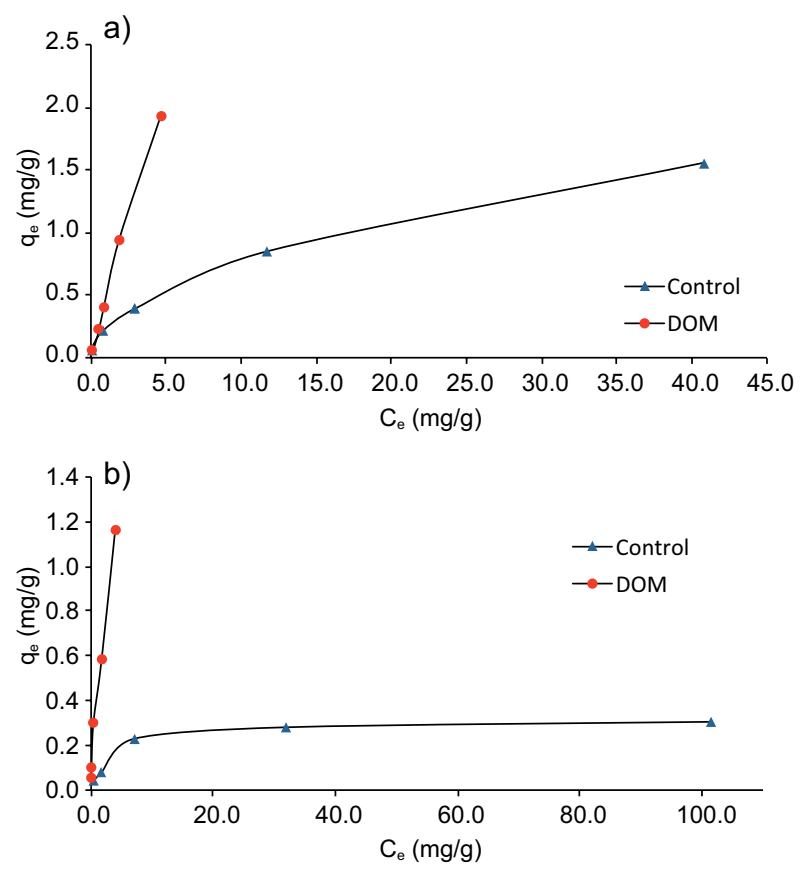

Fig. 1. Adsorption isotherms for the metals $\mathrm{Cu}(\mathrm{a})$ and $\mathrm{Zn} \mathrm{b}$ )

complexes (in which there is no water molecules between the surface functional groups and the ion), or by the van der Waals interactions in the sorptive process, causing specific adsorption (Sposito 1989, Refaey et al. 2014).

DOM is characterized by a large amount of humic and fulvic acids (Table II), which contributes positively to the adsorption. According to Rose et al. (1979), the abundance of carboxyl and hydroxyl radicals gives humic and fulvic acids the adsorption, complexation and chelation properties of metals, that when dissolved, have negative charge. Kiekens (1995) states thet zinc is preferentially retained by electrostatic forces, while copper is more effective in forming specific linkages, being more stable. Therefore, for this study, the adsorption scheme seems to be the following: DOM has high affinity for metal and forms a complex with it, which binds itself to the soil (Sposito 1989).

Another factor that may have influenced the best adsorption of copper and zinc in the presence of DOM is the $\mathrm{pH}$, since in our tests $\mathrm{pH}$ was higher (between 6.63 and 6.22 in solving balance) in relation to the control treatment (between 4.16 and 5.13). The effect of $\mathrm{pH}$ on the adsorption of metal cations is mainly the result of charges on soil particles. When $\mathrm{pH}$ increases, the electrostatic attraction of the soil by cations also increases and therefore the adsorption rises (Sposito et al. 1989, Alleoni et al. 2009). 
The Langmuir model was not suitable to describe the experimental results for $\mathrm{Cu}$ in the presence of dissolved organic matter. According to Alleoni et al. (2009), as well as the Freundlich model, the Langmuir equation best describes the adsorption on the surface of colloids and at low concentrations of the element. In addition, these models feature assumptions that are not fully applied to the soil system. As noted in figure 1a, $\mathbf{b}$, the adsorption of copper and zinc was more effective in the presence of the DOM; they were chemically adsorbed, possibly involving the exchange of ligands, which resulted in specific adsorption.

In non-specific adsorption, metals are adsorbed by positively charged surfaces, being weakly retained in a diffuse layer (Hingston et al. 1974), therefore they are best described by the equations of Langmuir and Freundlich. In this context, the models were suitable to describe the adsorption of $\mathrm{Cu}$ and $\mathrm{Zn}$ in the control treatment, which featured isotherms of type $\mathrm{L}$.

The parameters of Langmuir and Freundlich adsorption for copper and zinc are presented in table III. Although both models are well suited for the study of adsorption for the control treatment, the Freundlich isotherm obtained a higher determination coefficient $\left(\mathrm{R}^{2}=0.986\right)$ for the copper, and for zinc the Langmuir model was more appropriate, showing a greater determination coefficient $\left(\mathrm{R}^{2}=1.000\right)$.

According to the parameters given in table III for the Langmuir isotherm, it can be observed that the maximum capacity of adsorption $\left(q_{0}\right)$ and the binding energy $\left(K_{\mathrm{L}}\right)$ for zinc have increased considerably with the addition of the DOM, demonstrating the high affinity of the element with DOM.
Regarding the parameters found in the Freundlich isotherm (Table III), the values of $K_{\mathrm{F}}$ and $1 / n$ increased in the presence of DOM for copper and zinc. According to Sposito (1989) the value of $n$ is qualitatively related to the distribution of energy sites in soil colloids. In this work, the value of $1 / n$ was greater than $1(1 / n>1)$ for copper, indicating the presence of highly reactive binding sites. According to El Haddad et al. (2012), when $(1 / \mathrm{n}>1)$ the change in adsorbed concentration is greater than the change in the solute concentration.

\section{Leaching of copper and zinc}

The metals copper and zinc were leached from the beginning of the experiment as noted in figure $\mathbf{2 a}, \mathbf{b}$. It was observed, for the two metals under study, greater leaching up to approximately $450 \mathrm{~mL}$, from which occurs a tendency to stabilize the amount of metal carried in the soil.

The addition of DOM increased the copper leaching in soil, as demonstrated in figure 2a and confirmed by statistical analysis of regression lines (Table IV), where there was a significant differences at $5 \%$ between the treatment with DOM and the control treatment. However, the mass balance for the metal in the column revealed that only 1.04 and $3.02 \%$ were eluted for control and DOM, respectively, which demonstrates low $\mathrm{Cu}$ movement in the soil profile.

For zinc no differences were found between treatments (Table IV and Fig. 2b), which corroborates with the results obtained by Ashworth and Alloway (2004). The mass balance for this metal showed that there was an elution of 32.42 and $33.73 \%$ in control treatments and with DOM, respectively, indicating greater miscible displacement of $\mathrm{Zn}$ in relation to $\mathrm{Cu}$.

TABLE III. PARAMETERS OF THE LANGMUIR AND FREUNDLICH ISOTHERMS

\begin{tabular}{|c|c|c|c|c|c|c|}
\hline \multirow[t]{3}{*}{ Metal } & \multicolumn{3}{|c|}{ Langmuir } & \multicolumn{3}{|c|}{ Freundlich } \\
\hline & $\mathrm{q}_{0}(\mathrm{mg} / \mathrm{g})$ & $\mathrm{K}_{\mathrm{L}}(\mathrm{L} / \mathrm{mg})$ & $\mathrm{R}^{2}$ & $\mathrm{~K}_{\mathrm{F}}$ & $1 / \mathrm{n}$ & $\mathrm{R}^{2}$ \\
\hline & \multicolumn{6}{|c|}{ Control } \\
\hline Copper & 1.680 & 0.189 & 0.929 & 0.261 & 0.465 & 0.986 \\
\hline \multirow[t]{2}{*}{ Zinc } & 0.317 & 0.265 & 1.000 & 0.069 & 0.381 & 0.884 \\
\hline & \multicolumn{6}{|c|}{ DOM } \\
\hline Copper & N.A & N.A & N.A & 0.413 & 1.130 & 0.991 \\
\hline Zinc & 1.351 & 0.878 & 0.859 & 0.486 & 0.605 & 0.991 \\
\hline
\end{tabular}

N.A: not adjusted, DOM: dissolved organic matter 

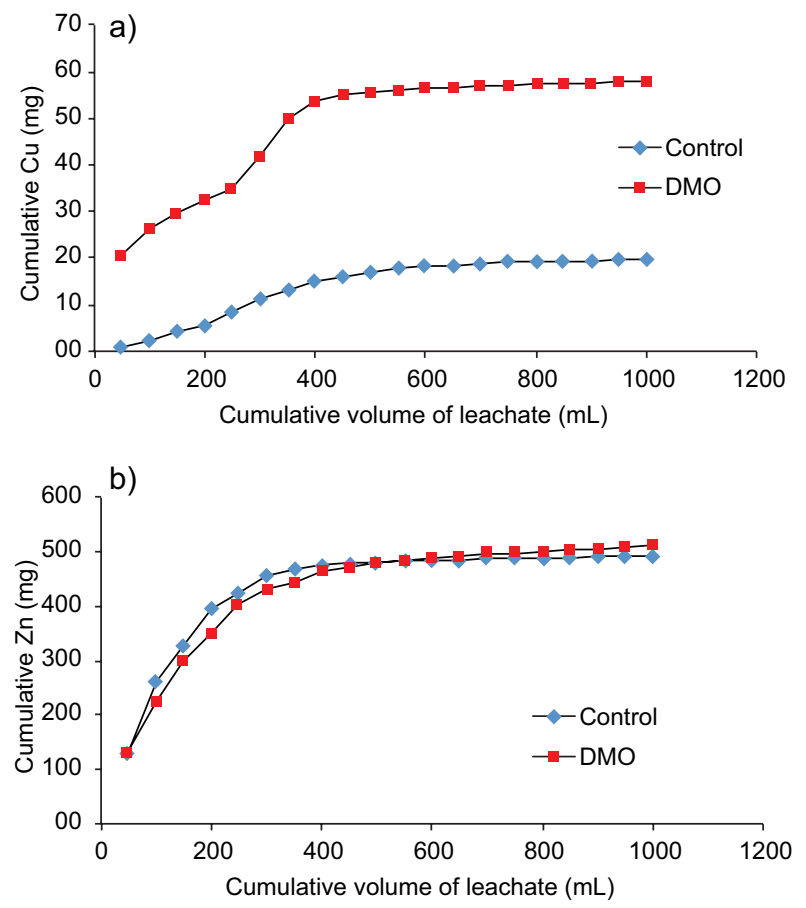

Fig. 2. Accumulated mass curves of metals $\mathrm{Cu}$ (a) and $\mathrm{Zn}$ (b) in leachate, in relation to the volume of leachate

TABLE IV. REGRESSION EQUATIONS SET FOR THE LEACHING OF COPPER AND ZINC

\begin{tabular}{lccc}
\hline Treatment & Equation & $\mathrm{R}^{2}$ & $\mathrm{p}$-value \\
\hline \multicolumn{4}{c}{ Copper } \\
\hline Control & $y=0.0403 x-1.63^{\mathrm{a}}$ & 0.993 & 0.000 \\
DOM & $y=0.0900 x+15.8^{\mathrm{b}}$ & 0.978 & 0.000 \\
\hline \multicolumn{4}{c}{ Zinc } \\
\hline Control & $y=0.792 x+182^{\mathrm{a}}$ & 0.830 & 0.001 \\
DOM & $y=0.816 x+154^{\mathrm{a}}$ & 0.900 & 0.000 \\
\hline
\end{tabular}

DOM: dissolved organic matter

Equal letters in the column represent equal lines by the test of comparison of regression lines at the $5 \%$ significance level.

The relative affinity of metals retained in the soil varies according to type of soil, amount of organic matter, CTC, pH, mineralogy, and clay quantity, as well as the properties of the metals (Mclean and Bledsoe 1992). In this study, there was greater retention of $\mathrm{Cu}$ in the soil compared to $\mathrm{Zn}$. Alleoni et al. (2009) reported that metals are specifically adsorbed in the preferred order: $\mathrm{Pb}>\mathrm{Cu}>\mathrm{Ni}>\mathrm{Cd}$ $>\mathrm{Zn}$. However, the formation of complexes between metals and the dissolved form of organic ligands (DOM) can affect the adsorption in soil and thus the mobility. The extent of complexation between a metal and soluble organic matter depends on the competition between the metal and the binding sites of the surface and organic ligand (Sposito 1989). In this sense, metals that rapidly form stable complexes with $\mathrm{DOM}$, as $\mathrm{Cu}$, are likely to be more mobile in the soil. Amrhein et al. (1992) demonstrated that metals such as $\mathrm{Cd}$ and $\mathrm{Zn}$, which are not highly stable complexes with organic matter, are not as greatly affected by the presence of dissolved organic matter in the soil. In this way, the type of percolator solution used in this experiment did not influence on leaching of $\mathrm{Zn}$, being able, possibly, to shift the metal present in the soluble fraction of the soil.

In a study by Li et al. (2016) in red soil in the presence of different phosphates, the authors observed that the concentration of $\mathrm{Cu}$ in leachates continuously increased during the whole leaching process for 10 days, while the concentration of $\mathrm{Zn}$ increased firstly and then decreased. The $\mathrm{pH}$ of the leachate increased continuously with the leaching time.

The $\mathrm{pH}$ of the soil system is a very important parameter, directly influencing sorption/desorption, precipitation/dissolution, complex formation, and oxidation-reduction reactions. Because of the complexity of the soil-waste system, with its myriads of surface types and solution composition, such a generalization may not be true. For example, cationic metal mobility has been observed to increase with increasing $\mathrm{pH}$ due to the formation of metal complexes with dissolved organic matter (Draszawka-Bolzan 2017).

During the leaching experiments for $\mathrm{Cu}, \mathrm{pH}$ values in the leachate ranged from 4.84 to 5.34 and from 4.37 to 5.67 for the control and the treatments with DOM, respectively. For $\mathrm{Zn}$, they varied from 4.69 to 6.74 and from 5.08 to 5.64 for control and DOM, respectively. All treatments showed a correlation between the $\mathrm{pH}$ and the amount of metal leached (in $\mathrm{mg}$ ) at a $5 \%$ level of significance. The copper control treatment showed the highest coefficient of determination $\left(\mathrm{R}^{2}=0.600\right)$, and the zinc treatment with DOM showed the highest coefficient of determination $\left(\mathrm{R}^{2}=0.773\right)$.

According to Harter (1983) and Georgiev et al. (2017), the transport and precipitation of pollutants depend strongly on the $\mathrm{pH}$ and the content of dissolved organic compounds in the soil solutions, which affect various retention mechanisms of metals in soils. McBride (1989) suggested that high values of $\mathrm{pH}$ promote the dissolution of soil organic matter and increase the concentration of total dissolved $\mathrm{Cu}$ by the formation of $\mathrm{Cu}$-organic complexes, also influencing the leaching. 


\section{CONCLUSIONS}

This study evaluated the effects of DOM from dairy cattle manure in the sorption and transportation of heavy metals in soil. The isotherms of adsorption for copper and zinc showed that sorption of metals in the soil was greater in the presence of DOM, possibly due to the availability of adsorption sites and interactions with the structure of the DOM and humic and fulvic acids.

The leaching of copper in soil was facilitated by the application of DOM; however, no differences were found in zinc leaching considering water or DOM. These results show the possibility of groundwater contamination as a result of metal mobility in the soil under study.

Considering the two experiments (sorption and leaching), each metal had a different behavior, even though both have a similar electronic configuration. This is possibly due to the $\mathrm{pH}$ change caused by the application of DOM in the system that affects the differential affinity for complexation sites.

\section{ACKNOWLEDGMENTS}

The authors thank the National Council for Scientific and Technological Development (CNPq) for financial support, as well as Fundação Araucária from Paraná and the Federal University of TechnologyParaná (UTFPR), for scholarship.

\section{REFERENCES}

Alleoni L.R.F., Mello J.W.V. and Rocha W.S.D. (2009). Eletroquímica, adsorção e troca iônica no solo. In: Química e mineralogia do solo. volume 2, Aplicações (Melo V.F. and Alleoni L.R.F., Eds.). Sociedade Brasileira de Ciência do Solo, Viçosa, Brazil, pp. 70-129.

APHA (1998). Standard methods for the examination of water and wastewater. 20th ed. American Public Health Association. Washington, EUA, 1325 pp.

Amrhein C., Strong J.E. and Mosher P.A. (1992). Effect of deicing salts on metal and organic matter mobility in roadside soils. Environ. Sci. Techno. 26 (4), 703-709. http://doi.org/10.1021/es00028a006

Antonladis V. and Tsadilas C.D. (2007). Sorption of cadmium, nickel and zinc in mono and multimetal systems. Appl. Geochem. 22 (11), 2375-2380. http:// doi.org/10.1016/j.apgeochem.2007.06.001

Ashworth D.J. and Alloway B.J. (2004). Soil mobility of sewage sludge-derived dissolved organic matter, copper, nickel and zinc. Environ. Pollut. 127 (1), 137144. http://doi.org/10.1016/S0269-7491(03)00237-9

Benedetti M.F., Van Riemsdijk W.H., Koopal L.K., Kinniburgh D.G., Gooddy D.C. and Milne C.J. (1996). Metal ion binding by natural organic matter: From the model to the field. Geochim. Cosmochim. Acta 60 (14), 2503-2513. http://doi.org/10.1016/00167037(96)00113-5

Benites V.M., Madari B. and Machado P.L.O. (2003). Extração e fracionamento quantitativo de substâncias húmicas do solo: um procedimento simplificado de baixo custo. Brazilian Agricultural Research Corporation, Rio de Janeiro, Brazil, 7 pp.

Corrêa M.M., Lima L.A., Martinez M.A., Riginato R.L.O. and Sampaio S.C. (1999). Deslocamento miscível de sulfona de aldicarbe em colunas de solo. Rev. Bras. Eng. Agríc. Ambient. 3 (2), 217-221. http://doi. org/10.1590/1807-1929/agriambi.v3n2p217-221

Draszawka-Bolzan B. (2017). Effect of $\mathrm{pH}$ and soil environment. World News of Natural Sciences 8, 50-60.

Embrapa (1997). Manual de métodos de análise de solo. 2nd ed. Brazilian Agricultural Research Corporation, Centro Nacional de Pesquisas de Solos. Rio de Janeiro, Brazil, 212 pp.

El Haddad M., Mamouni R., Saffaj N. and Lazar S. (2012). Removal of a cationic dye - Basic Red 12 - from aqueous solution by adsorption onto animal bone meal. J. Assoc. Arab. Univer. Basic. Appl. Sci. 12 (1), 48-54. http://doi.org/10.1016/j.jaubas.2012.04.003

Embrapa (2006). Sistema brasileiro de classificação de solos. 2nd ed. Brazilian Agricultural Research Corporation, Centro Nacional de Pesquisas de Solos. Rio de Janeiro, Brazil, 353 pp.

Franzetti A., Caredda P., Ruggeri C., La Colla P., Tamburini E., Papacchini M. and Bestetti G. (2009). Potential applications of surface-active compounds by Gordonia sp. strain BS29 in soil remediation technologies. Chemosphere 75 (6), 801-807. http://doi.org/10.1016/j. chemosphere.2008.12.052

Georgiev P., Groudev S., Spasova I. and Nicolova M. (2017). Transport of radionuclides and heavy metals during the cleanup of a polluted cinnamonic soil. J. Geochem. Explor. 174, 148-158. http://doi. org/10.1016/j.gexplo.2016.03.014

Harter R.D. (1983). Effect of soil pH on sorption of lead, copper, zinc and nickel. Soil Sci. Soc. Am. J. 47 (1), 47-51. http://doi.org/10.2136/sssaj1983.03615995004 700010009x

Hingston F.J., Posner A.M. and Quirk J.P. (1974). Anion adsorption by goethite and gibbsite. II. Desorption of anions from hydrous oxide surfaces. J. Soil Sci. 25 (1), 16-26. http://doi.org/10.1111/j.1365-2389.1974. tb01098.x 
Juwarkar A.A., Nair A., Dubey K.V., Singh S.K. and Devotta S. (2007). Biosurfactant technology for remediation of cadmium and lead contaminated soils. Chemosphere 68 (10), 1996-2002. http://doi.org/10.1016/j. chemosphere.2007.02.027

Kiekens L. (1995). Zinc. In: Heavy metals in soils (Alloway B.J., Ed.). Chapman and Hall, London, UK, pp. 284-303.

Li Z. and Zhou L. (2010). Cadmium transport mediated by soil colloid and dissolved organic matter: A field study. J. Environ. Sci. 22 (1), 106-115. http://doi.org/10.1016/ S1001-0742(09)60081-4

Li Z., Huang B., Huang J., Chen G., Xiong W., Nie X., Ma W. and Zeng G. (2016). Influence of different phosphates on adsorption and leaching of $\mathrm{Cu}$ and $\mathrm{Zn}$ in red soil. Trans. Nonferrous Met. Soc. China 26 (2), 536543. http://doi.org/10.1016/S1003-6326(16)64142-0

McBride M.B. (1989). Reactions controlling heavy metal solubility in soils. Adv. Soil Sci. 10, 1-55. http://doi. org/10.1007/978-1-4613-8847-0_1

McLean J.E. and Bledsoe B.E. (1992). Behavior of metals in soils. Environmental Protection Agency, Washington, EUA, 25 pp.

Nieder R., Benbi D.K. and Isermann K. (2003). Soil organic matter dynamics. In: Handbook of processes and modeling in the soil-plant system (Benbi D.K. and Nieder R., Eds.). Food Product Press, New York, EUA, pp. 345-408.

Refaey Y., Jansen B., El-Shater A., El-Haddad A. and Kalbitz K. (2014). The role of dissolved organic matter in adsorbing heavy metals in Clay-Rich soils. Vadose Zone J. 13 (7), 1-12. http://doi.org/10.2136/ vzj2014.01.0009

Refaey Y., Jansen B., Parsons J.R., Voogt P., Bagnis S., Markus A., El-Shater A., El-Haddad A. and Kalbitz K. (2017). Effects of clay minerals, hydroxides, and timing of dissolved organicmatter addition on the competitive sorption of copper, nickel, and zinc: A column experiment. J. Environ. Manage. 187 (1), 273-285. http://doi.org/ 0.1016/j.jenvman.2016.11.056
Rose A.W., Hawkes H.E. and Webb J.S. (1979). Geochemistry in mineral exploration. Academic Press, New York, USA, $657 \mathrm{pp}$.

Scherer E.E., Aita C. and Baldissera I.T. (1996). Avaliação da qualidade do esterco líquido de suínos da região Oeste Catarinense para fins de utilização como fertilizante. Agricultural Research and Rural Extension Company of Santa Catarina, Florianópolis, Brazil, $46 \mathrm{pp}$.

Song N.H., Chen L. and Yang, H. (2008). Effect of dissolved organic matter on mobility and activation of chlorotoluron in soil and wheat. Geoderma 146 (1-2), 344-352. http://doi.org/10.1016/j.geoderma.2008.05.031

Sposito G. (1989). The chemistry of soils. Oxford University Press, New York, USA, 234 pp.

Sun B., Zhao F.J., Lombi E. and McGrath S.P. (2001). Leaching of heavy metals from contaminated soils using EDTA. Environ. Pollut. 113 (2), 111-120. http://doi.org/10.1016/S0269-7491(00)00176-7

Tedesco M.J., Gianello C., Bissani C.A., Bohnen H. and Volkweiss S.J. (1995). Análises de solo, plantas e outros materiais. 2nd ed. Departamento de Solos, UFRGS, Porto Alegre, Brazil, 174 pp.

Temminghoff E.J.M., Zee S. and Haan F. (1997). Copper mobility in a copper-contaminated sandy soil as affected by $\mathrm{pH}$ and solid and dissolved organic matter. Environ. Sci. Technol. 31 (4), 1109-1115. http://doi. org/10.1021/es9606236

Yongkui Y., Li L. and Dingyong W. (2008). Effect of dissolved organic matter on adsorption and desorption of mercury by soils. J. Environ. Sci. 20 (9), 1097-1102. http://doi.org/10.1016/S1001-0742(08)62155-5

Zhou L.X., Zhou S.G. and Zhan X.H. (2004). Sorption and biodegradability of sludge bacterial extracellular polymers in soil and their influence on soil $\mathrm{Cu}$ behavior. J. Environ. Qual. 33 (1), 154-162.http://doi. org/10.2134/jeq2004.1540 